\title{
Prenatal Testing Gone Awry: The BirTh of A CONFLICT OF ETHICS AND LIABILITY
}

\author{
Elizabeth A. Ackmann*
}

\section{INTRODUCTION}

In today's world of constantly evolving technology, a pregnant woman can know many details about the fetus inside of her before it is born. Although most of the prenatal testing that is commonly conducted in the United States is not brand-new technology, expansions in tort law for both wrongful death and medical malpractice have brought a new focus on prenatal testing and to the physicians and health care workers who are administering and interpreting the tests.

The recent prevalence of medical malpractice claims has resulted in the claim of medical malpractice being used in different cases. This topic is a novel issue because there is a potential for recovery for fetal torts under the theory of malpractice where the same suit would be dismissed under the guise of a wrongful death claim. Even if medical malpractice claims are curtailed by legislation in the coming years, the "viability" or "quickening"1 standards used by many states to block wrongful death claims of a fetus might have to be reevaluated as medical technology effectively moves forward the date when a fetus could be considered viable. Further, this topic is noteworthy from the standpoint of the actual process of genetic screening. The expansion of medical malpractice liability could extend to the medical technologists who perform the prenatal tests and to the genetic counselors who play important roles in relaying information and options to women carrying fetuses with indicated problems. Finally, the issue of medical malpractice with regard to faulty prenatal testing is complicated by the fact that the women choose to terminate their pregnancies. The choice to terminate might affect a court or jury's determination of potential liability on the physician or genetic counselors.

The issue of a woman's decision to terminate her pregnancy based on an incorrect prenatal test interpretation was brought before the Georgia Court of Appeals in December, 2002. In Breyne v. Potter, the Georgia Court of Appeals recognized a cause of action for a forty-year-old woman who aborted her fetus based on her physician's recommendation. ${ }^{2}$ The woman's obstetrician told her on two separate occasions that the results of the test indicated that

* J.D. Candidate, 2005, Indiana University School of Law- Indianapolis; B.A., 2000, Purdue University, West Lafayette, Indiana. The author wishes to thank Mary Hoeller and Shelley Fraser for their invaluable assistance and advice. "viability."

1. See Parts II.B and II.C, infra, for a discussion on the definitions of "quickening" and

2. Breyne v. Potter, 574 S.E.2d 916 (Ga. Ct. App. 2002). 
the fetus had Down's Syndrome, and he recommended that if she was considering an abortion that she act quickly because of the advanced gestational age of the fetus. ${ }^{3}$ The woman chose to have an abortion. ${ }^{4}$ However, the obstetrician had misread the test results on two separate documents provided to him by the lab, and in fact, the fetus had trisomy-X. ${ }^{5}$ Trisomy-X does not generally lead to gross physical abnormalities although the exact effects on children vary from case to case. ${ }^{6}$ The obstetrician informed the woman of his mistake after the abortion but indicated to her that trisomy- $\mathrm{X}$ was an affliction with similar symptoms and trademark character traits to Down's Syndrome. ${ }^{7}$ The reality is some people born with trisomy- $X$ have no phenotypical signs of the abnormality and lead very normal lives. ${ }^{8}$

After the trial court ruled in favor of the obstetrician, the woman prevailed on her appeal to the appellate court in Georgia. ${ }^{9}$ However, the court was clear in pointing out the judgment for the woman was based on the fact that her claim was a medical malpractice claim and not a wrongful death claim. ${ }^{10}$ Georgia's rule of law stipulates that no cause of action exists for the wrongful death of an unborn child who was not "quick" or "viable" at the time the fetus died. ${ }^{11}$

This Note will discuss the effect a woman's choice to abort her fetus could have on the physician who incorrectly interpreted a prenatal test and advised the woman to consider termination of the pregnancy. Although many states do not recognize a wrongful death cause of action for a fetus, recovery is still possible in the form of a medical malpractice claim. Part I of this Note discusses the basics of prenatal testing, addresses the background of a fetus within the law, and notes the evolution of the tort of wrongful birth. Part II discusses wrongful death, policy issues behind denying a wrongful death claim, an explanation of the quickening and viability standards, suggesting that the abolition of those benchmarks would lead to more acceptance of fetal wrongful death. Part III outlines medical malpractice claims and the greater possibility of recovery under this tort. Part IV addresses how a woman's choice to terminate a pregnancy affects the outcome for recovery and creates a conflict with the recognized right of a woman to be able to make that choice. Part V determines that while it is possible prenatal diagnostic laboratories and genetic counselors could be held vicariously liable for their involvement, their lack of education and training in comparison to the physician will likely mitigate their case.
3. Id. at 918.
4. Id.
5. Id.
6. Id.
7. Id.
8. Breyne, 574 S.E.2d at 918 .
9. Id.
10. Id.
11. Id. at 919. 


\section{SUCCESSFUL CONCEPTION... WHAT HAPPENS WHEN A GOOD THING GOES WRONG?}

\section{A. Prenatal Testing: Success and Acceptability Growing into a Problem}

Prenatal testing has not varied much in technique since the advent of the use of amniocentesis in $1966,{ }^{12}$ and it is still widely accepted and applied. The appreciable difference from nearly forty years ago is the result of the near completion of the Human Genome Project. This project has resulted in the identification and mapping of more genes, which leads to the possibility of detection of more genetic abnormalities from the routine prenatal tests. Generally, the specimens drawn from pregnant women are sent to a specialized lab which only analyzes specimens related to prenatal testing. In one prenatal diagnostic laboratory in Indiana, the DNA is mapped by individual technicians, and potentially abnormal tests are reanalyzed by at least four additional technicians. ${ }^{13}$ The most common prenatal genetic screening tests done today in the United States are the maternal triple screen, amniocentesis, and chorionic villi sampling. ${ }^{14}$

The Maternal Triple Screen test is performed in most, if not all, pregnancies. A blood sample is obtained from the woman between the sixteenth and eighteenth week of pregnancy to test for afflictions like spina bifida and chromosomal abnormalities like Down's Syndrome. ${ }^{15}$ A component of the Maternal Triple Screen is the alpha-fetoprotein test, which is commonly referred to singularly (the AFP test), although it is considered part of the triple screen. ${ }^{16}$ The risk associated with the AFP/Maternal Triple Screen is far less than an amiocentesis or chorionic villi sampling because it is obtained by a blood sample from the woman rather than obtaining a sample of cells from the woman's uterus via needle in the abdomen. ${ }^{17}$ However, AFP can also be done with amniotic supernatant fluid. ${ }^{18}$

Amniocentesis is a procedure in which cells are harvested from the amniotic fluid surrounding the fetus. ${ }^{19}$ The fluid is usually obtained by

12. Michael J.Malinowski, Coming into Being: Law, Ethics, and the Practice of Prenatal Genetic Screening, 45 HASTINGS L.J. 1435, 1445 (1994).

13. Interview with Angela $M$. Reese, CLSp(CG) [Clinical Lab Specialist in Cytogenetics], Indiana University School of Medicine, Indianapolis, Ind. (Aug. 1, 2003).

14. David Stoller, Prenatal Genetic Screening: The Enigma of Selective Abortion, 12 J.L. \& HEALTH 121, 123 (1997).

15. Jean H. Priest \& Kathleen W. Rao, Prenatal Chromosome Diagnosis, in The AGT CYTOGENETICS LABORATORY MANUAL 200 (Margaret J. Barch, et al. eds., Lippincott-Raven, 3rd ed. 1997).

16. Priest \& Rao, supra note 15 , at 200.

17. Id.

18. Supernatant amniotic fluid is analogous to the plasma component of blood. It is the amniotic fluid that has had the cells extracted from it already. Id.

19. Stoller, supra note 14 , at 123. 
inserting a large needle into the woman's abdomen. The drawbacks include: the test is usually not performed before the fifteenth or sixteenth week of pregnancy, the results take a couple of weeks to obtain due to the need to harvest the cells, and there is a chance of miscarriage associated with amniocentesis. ${ }^{20}$ However, the test may be performed as early as the eleventh to the fourteenth week of pregnancy, depending on a patient's needs. ${ }^{21}$ Because of the potential risk of miscarriage, amniocentesis is traditionally performed on older women who have a higher risk of bearing children with chromosomal abnormalities such as Down's Syndrome. ${ }^{22}$

Chorionic Villi Sampling (CVS) takes cells from the chorionic villi, which are "hair-like projections that surround the embryo in the early stages of pregnancy."23 A physician will use ultrasound to guide a catheter through the cervix to obtain the chorionic villi. This test is beneficial because it must be performed before the tenth week, and no incubation time is needed to harvest the cells; however, a higher risk of miscarriage exists with this type of test compared to an amniocentesis due to the more invasive nature of the procedure. ${ }^{24}$

The previously mentioned Human Genome Project, which began in 1989 , stands to greatly expand the possibilities of prenatal genetic testing. ${ }^{25}$ "Specifically, with each success in identifying a genetic abnormality associated with the onset of a specific health impairment comes the potential to test fetuses for the presence of that genetic abnormality." ${ }^{\text {"26 }}$ Compared to the early years of prenatal testing, genetic screening today can detect a wider array of abnormalities than the basic chromosomal abnormalities that the tests could identify in the beginning years of prenatal testing. Now, as scientists uncover more details about other characteristics of humans already utilized from conventional prenatal testing, parents are able to know far more about their child's future than they have in the past. The completion of the human genetic "roadmap" potentially could allow parents the opportunity to abort their fetuses for less serious abnormalities and could present problems for genetic screening

20. Id.

21. Priest \& Rao, supra note 15 , at 199-200.

22. Simmons v. W. Covina Med. Clinic, 212 Cal. App. 3d 696, 699-700 (Cal. Ct. App. 1989).

23. Stoller, supra note 14 , at 123.

24. $I d$.

25. The Human Genome Project is a government-funded, $\$ 300$ billion project with the goals of assembling a complete map of the human genetic framework and identifying the base pairs of nucleotides - comprised of the building blocks of Adenine, Thymine, Cytonine and Guanine-for each gene. The basic genetic map was completed in 2002, identifying 30,000 genes in the human genome. Michael J. Malinowski, Choosing the Genetic Makeup of our Children: Our Eugenics Past-- Present, and Future?, 36 CONN. L. REV. 125, 172 (2003).

26. Malinowski, supra note 12, at 1445. 
laboratories which could be forced to limit the genetic abnormalities they will analyze. $^{27}$

\section{B. The "Birth" of a Fetus Within the Context of the Law}

At common law, there was no possibility for a wrongful death recovery for a fetus. ${ }^{28}$ Dietrich $v$. Northampton is the landmark case that first recognized the tort of wrongful death for a fetus which died as a result of its mother falling on a sidewalk. ${ }^{29}$ Justice Holmes reasoned the fetus is still considered to be a part of its mother, and no separate duty existed with respect to the fetus, which essentially meant that the fetus' chance for recovery was "piggybacked" on to its mother's possibility of recovery. ${ }^{30}$ Bonbrest $v$. Kotz was the first case to allow recovery for a fetal injury if the fetus had attained viability, noting that "apart from viability, a non-viable foetus [sic] is not a part of its mother."31 Although the cause of action in Bonbrest was medical malpractice, it was the first step in rapid change towards allowing a basis for recovery in wrongful death. ${ }^{32}$

The Bonbrest court based its ruling on the premise "[a] child en ventre sa mere $^{33}$ is not only regarded as human being, but as such from the moment of conception-which it is in fact." 34 The Bonbrest decision notes the departure from the common law concepts that the woman and child were one unit and that a separate duty of care was not owed to the child. ${ }^{35}$ The Bonbrest rule is that a child, if born alive and viable, should be allowed to maintain an action in the courts for injuries wrongfully committed upon its person while in the womb of its mother. ${ }^{36}$

Following the Bonbrest decision, the tort of fetal injury expanded to include claims involving direct fetal injury and/or subsequent miscarriages associated with auto accidents or similar traumatic injury to the woman. ${ }^{37}$

27. The future societal problems range anywhere from eugenics, the practice of selectively terminating pregnancies based on the presence of more phenotypical genes, to the possibility of discrimination down the road stemming from people who are known to carry certain genes. See, e.g., Stoller, supra note 14, at 123, and Anita Silvers \& Michael Ashley Stein, Human Rights and Genetic Discrimination: Protecting Genomics' Promise for Public Health, 31 J.L. MED. \& ETHICS 377 (2003).

28. Dietrich v. Northampton, 138 Mass. 14, 17 (1884).

29. Id. at 14.

30. 66 Fed. Credit Union v. Tucker, 853 So.2d 104, 107 (Miss. 2003).

31. Bonbrest v. Kotz, 65 F. Supp. 138, 140 (D.C. 1946).

32. Id. at 140 .

33. En ventre sa mare means "In the mother's womb." BLACK's LAW DICTIONARY 226 (1st Pocket ed.1996).

34. Bonbrest, 65 F. Supp. at 140.

35. Id. at 139 .

36. Id. at 142 .

37. See, e.g., 66 Fed. Credit Union v. Tucker, 853 So.2d 104 (Miss. 2003); Toth v. Goree, 237 N.W.2d 297 (Mich. Ct. App. 1976). 


\section{Wrongful Birth: The Scourge of Public Policy}

Another prominent fetal tort is wrongful birth, in which parents sue based on the theory they would have aborted the child had they known the child would be born with genetic abnormalities that would seriously affect his/ her quality of life. A Kentucky court explained that in the state of Kentucky, the tort of wrongful birth is not a new claim but rather "a traditional medical negligence claim requiring the elements of duty, breach, causation, and injury to be proven for the plaintiffs to prevail.",38

Wrongful birth claims are merely medical malpractice claims, and some states hesitate to categorize them in a separate area of tort law, given most states have established specific statutory and/or case law-based procedural guidelines for medical malpractice claims. In Bader v. Johnson, the Indiana Supreme Court noted it "[saw] no reason for compounding or complicating [the] medical malpractice jurisprudence by according this particular form of professional negligence action some special status apart from presently recognized medical malpractice or by giving it the new name of "wrongful birth.",39

In contrast, Maryland recognizes the tort of wrongful birth because "[e]ven though the physical forces producing [the baby's] birth defects were already in operation at the time of the alleged negligence of the physicians, under the chain of causation alleged by [the parents], the physicians could have prevented the harm to the parents." ${ }^{\circ 0}$ Under this theory, the parents and children are considered equally, and this appears to violate the idea the fetus/ infant is separate from the woman. The notion of the close parental and child relationship is connected to the "zone of danger" theory of torts, which allows family members to recover for emotional distress suffered by witnessing harm to close family members. There is hesitation to allow recovery for emotional distress in wrongful birth actions based on a reluctance to expand the tort of emotional distress. ${ }^{41}$

In states that do not recognize wrongful birth, there is more emphasis placed on the life of the child and the fact that allowing damages for a child to be born is contradictory to public policy and morality. ${ }^{42}$ The Supreme Court of North Carolina stated recognizing wrongful birth equates a "holding that the existence of a human life can constitute an injury cognizable at law."43

Abolishing wrongful birth in favor of bringing those claims under traditional medical negligence is probably not a smart decision in light of the 2003).

38. Grubbs v. Barbourville Family Health Ctr. P.S.C., 120 S.W.3d 682, 684-85 (Ky.

39. Bader v. Johnson, 732 N.E.2d 1212, 1216 (Ind. 2000) (quoting Greco v. United States, 893 P.2d 345, 348 (Nev. 1995)).

40. Reed v. Campagnolo, 630 A.2d 1145, 1146 (Md. 1993).

41. See, e.g., Siemieniec v. Lutheran Gen. Hosp., 512 N.E.2d 691 (IIl. 1987).

42. Azzolino v. Dingfelder, 337 S.E.2d 528, 534 (N.C. 1985).

43. Id. at 534 . 
prominence of prenatal genetic testing. While the policy argument of valuing the life of the child is compelling, this nation has recognized the fundamental right of a woman to choose to have an abortion. In that sense, if a woman is denied the opportunity to make the choice to terminate a pregnancy due to a genetic abnormality, the birth of that child could be considered "wrongful." The state's interest in protecting the life of a fetus would not have come into fruition if the woman had been given an opportunity to exercise her right to an abortion. As long as abortion is legal, the tort of wrongful birth should exist.

\section{WRONGFUL DEATH}

\section{A. The Development of a New Tort}

The Supreme Court of Indiana noted "“wrongful birth' seems to have its genesis as a play upon the statutory tort of "wrongful death." words, wrongful death was the first tort from which the others derived. "The purposes of the wrongful death statute are to prevent the wrongful termination of life and provide the beneficiary with compensation for the loss of companionship and society of the deceased, the pain and suffering of the deceased between injury and death, and punitive damages." ${ }^{, 45}$ Mississippi's standards for determining a cause of action for wrongful death are that "[a] jury must determine whether or not a wrongful death has occurred, who, if anyone, is the tortfeasor, and finally, whether damages, if any, should be awarded."46 This reliance on the jury could result in sympathy verdicts, especially in this cause of action where the woman has lost a child, if the jury is comprised of parents. These sympathy verdicts would be granted without any consideration for the elements associated with the cause of action.

Despite the potential of having a sympathetic jury, especially if you are the defendant health care worker, on its face, the tort of wrongful death seems ethically less controversial than wrongful birth, until it is applied to a fetus. There are problems associated with having a cause of action for fetuses via wrongful death statutes. The main problem is the determination of when to recognize the possibility of a wrongful death suit for a fetus. The first method utilized was the "born alive" rule from the Bonbrest decision. ${ }^{47}$ The harshness of this rule with respect to the inability for recovery for fetal injury or death has led many states to replace the born alive standard with the viability standard, and only eleven states maintain the 'born alive' rule for fetuses. ${ }^{48}$ These

44. Bader, 732 N.E.2d at 1216.

45. 66 Fed. Credit Union v. Tucker, 853 So.2d 104, 109-10 (Miss. 2003).

46. Id. at 115 .

47. See Part I.B, supra, for a discussion of the Bonbrest v. Katz rule.

48. See Chatelain v. Kelley, 910 S.W.2d 215 (Ark. 1995); Bayer v. Settle, 100 Cal. Rptr. 212 (Cal. Ct. App. 1972); Stokes v. Liberty Mutual Ins. Co., 213 So.2d 695 (Fla. 1968); Weitl v. Moes, 311 N.W.2d 259 (Iowa 1981); Milton v. Cary Med. Ctr., 538 A.2d 252 (Me. 1988); 
states' adhesion to the harsh rule is a strict reliance on statutory interpretation: "[c]ourts adopting the born-alive rule look at the applicable statute, and if no statutory guidance is given, assume that an unborn child does not fit the definition of 'person' so as to fall within the statute's protection." ${ }^{" 49}$ Twenty-eight states and the District of Columbia do not recognize wrongful death as a cause of action for a fetus that is not viable. ${ }^{50}$

\section{B. Quickening Standard}

Because the determination of a quick and/or viable fetus is so lucid due to the different progressions of each pregnancy and the difficulty in occasionally pinpointing the age of the fetus, it is difficult, as a matter of law, to set guidelines for courts to follow. Some courts have set basic definitions to use in their consideration of these types of cases. The Georgia Court of Appeals defined quickening as "some form of fetal movement that the woman can feel, such as the fetus kicking a leg. [Q] uickening generally occurs sometime between the tenth week and fourth month of pregnancy." 51 The court clarified its position on the fetal movement by holding the "heartbeat alone is not sufficient movement to constitute quickening." $" 52$ However, twenty years prior to this definition of quickening, the Georgia Court of Appeals held " $[t]$ he mere fact that appellant had not felt the movement of the fetus does not necessarily mean that the fetus did not move or was not capable of movement at the time

Graf v. Taggert, 204 A.2d 140 (N.J. 1964); In re Estate of Logan, 144 N.E.2d 644 (N.Y. 1957); Hogan v. McDaniel, 319 S.W.2d 221 (Tenn. 1958), Wittyv. Am. Gen. Capital Distributors, 727 S.W.2d 503 (Texas 1987); Webb v. Snow, 132 P.2d 114 (Utah 1942); Kalafut v. Gruver, 389 S.E.2d 681 (Va. 1990).

49. Murphy S. Klaising, The Death of an Unborn Child: Jurisprudential Inconsistencies in Wrongful Death, Criminal Homicide, and Abortion Cases, 22 PEPP. L. REV. 933,940(1995).

50. See Wade v. United States, 745 F. Supp. 1573 (D. Hawaii 1990); Espadero v. Feld, 649 F. Supp. 1480 (D. Colo. 1986); Simmons v. Howard Univ., 323 F. Supp. 529 (D.C. 1971); Eich v. Town of Gulf Shores, 300 So.2d 354 (Ala. 1974); Summerfield v. Super. Ct., 689 P.2d 712 (Ariz. 1985); Hatala v. Markiewicz, 224 A.2d 406 (Conn. Super. Ct. 1966); Worgan v. Greggo \& Ferrara, Inc., 128 A.2d 557 (Del. Super. Ct. 1956); Volk v. Baldazo, 651 P.2d 11 (Idaho 1982); Seef v. Sutkus, 583 N.E.2d 510 (IIll. 1991); Britt v. Sears, 277 N.E.2d 20 (Ind. 1971); Hale v. Manion, 368 P.2d 1 (Kan. 1962); Rice v. Rizk, 453 S.W.2d 732 (Ky. Ct. App. 1970); State, Use of Odham v. Sherman, 198 A.2d 71 (Md. 1964); Mone v. Greyhound Lines, Inc., 331 N.E.2d 916 (Mass. 1975); O'Neill v. Morse, 188 N.W.2d 785 (Mich. 1971); State v. Soto, 378 N.W.2d 625 (Minn. 1985); Strzelczyk v. Jett, 870 P.2d 730 (Mont. 1994); White v. Yup, 458 P.2d 617 (Nev. 1969); Wallace v. Wallace, 421 A.2d 134 (N.H. 1980); Salazar v. St. Vincent Hosp., 619 P.2d 826 (N.M. Ct. App. 1980); DiDonato v. Wortman, 358 S.E.2d 489 (N.C. 1987); Hopkins v. McBane, 359 N.W.2d 862 (N.D. 1984); Werling v. Sandy, 476 N.E.2d 1053 (Ohio 1985); Libbee v. Permanente Clinic, 518 P.2d 636 (Or. 1974); Coveleski v. Bubnis, 634 A.2d 608 (Pa. 1993); Fowler v. Woodward, 138 S.E.2d 42 (S.C. 1964); Vaillancourt v. Med. Ctr. Hosp. of Vermont, Inc., 425 A.2d 92 (Vt. 1980); Moen v. Hanson, 537 P.2d 266 (Wash. 1975); Kwaterski v. State Farm Mut. Auto. Ins. Co., 148 N.W.2d 107 (Wis. 1967).

51. Citron v. Ghaffari, 542 S.E.2d 555, 557 (Ga. Ct. App. 2000).

52. Id. at 555 . 
of the unborn child's death." 53 This broad interpretation of the concept of quickening was almost certainly problematic for courts to handle, and there is little evidence that could be admitted or presented on either side as proof of quickening apart from the woman's own testimony.

\section{The Viability Standard's Many Downfalls}

Viability of the fetus occurs at a point later in the pregnancy, although, like quickening, it is equally difficult to attach it to a specific gestational age. In the Supreme Court's landmark abortion case Roe v. Wade, the Court stated "[v]iability is usually placed at about seven months ([twenty-eight] weeks) but may occur earlier, even at [twenty-four] weeks." 54 However, less than twenty years later in Planned Parenthood $v$. Casey, ${ }^{55}$ the Supreme Court estimated viability likely occurs closer to twenty-three or twenty-four weeks' gestation. ${ }^{56}$ In addition to relying solely on the gestational age of a fetus, the Supreme Court identified several factors to consider in identifying whether or not a fetus is viable: the gestational age of the fetus, derived from the reported menstrual history of the woman; fetal weight, based on an inexact estimate of the size and condition of the uterus; the woman's general health and nutrition; the quality of the available medical facilities; and other factors. ${ }^{57}$ However, the Court cautioned against placing complete reliance on these factors largely because of the relatively large number of factors and the fact that many of the statistics associated with the factors vary greatly from person to person, making a fetus' chances of "obtaining meaningful life outside the womb" very difficult to determine. ${ }^{58}$ Further, the Court noted some physicians, even if they have determined a probability of survival for the fetus, will only say a fetus is viable if they have determined a specific chance of survival, and some physicians will not associate viability with any percentage of survival. ${ }^{59}$

53. Shirley v. Bacon, 267 S.E.2d 809, 811 (Ga. Ct. App. 1980).

54. Roe v. Wade, 410 U.S. 113, 160 (1973). The other notion to consider is the fact medical technology has evolved since the Roe decision in 1973. When Roe was decided, "a twenty-eight week old fetus had about a one in ten chance of surviving," but today, babies born at twenty-eight weeks' gestation have a much greater chance of surviving. Klaising, supra note 49 , at 941 .

55. Planned Parenthood v. Casey, 505 U.S. 833, 873 (1992).

56. Klaising, supra note 49, at 947 (citing Casey, 505 U.S. at 860 ).

57. Colautti v. Franklin, 439 U.S. 379, 395 (1979).

58. Id. at 395.

59. For example, a physician might say a fetus is viable if it has a seventy-five percent chance of survival, whereas another physician might call a fetus viable if it only has a fifty percent chance of survival, based on each physician's personal belief. Id. 


\section{The Abolition of Any Special Standard for Fetal Wrongful Death}

The Supreme Court of West Virginia abolished the distinction in case law for nonviable versus viable fetuses in the 1995 decision of Farley $v$. Sartin. ${ }^{60}$. The Farley case was a wrongful death claim filed against a truck driver and his company following the death of a woman who was approximately eighteen weeks' pregnant at the time of the crash. ${ }^{61}$ That court noted adjudicating cases involving nonviable and viable fetuses in the same manner, recognizing that a cause of action exists for all fetuses regardless of viability, saves a trial court from having to undergo the factual analysis of determining whether the fetus is viable, and it allows for families to recover because their loss is not any less traumatic because the fetus is not viable. ${ }^{62}$

Although the standards for determining whether there has been a wrongful death of a fetus are not very clear, much less even recognized by most states, wrongful death is something that should be reconsidered to apply to all fetuses, and state legislatures should reexamine the issue to avoid forcing a court to make a decision on the issue. ${ }^{63}$ Perhaps the most compelling reason is it allows for recovery when recovery may not be possible under any other application of the law. ${ }^{64}$ The Supreme Court of South Dakota noted "someone could fatally injure an unborn child by a nonconsensual, wrongful act and still avoid civil liability because the child was not yet viable ... . [This] would, ironically, give the tortfeasor the same civil rights as the mother to terminate a pregnancy."65

This recognition of wrongful death for a fetus as a possibility of recovery and punishment for the tortfeasor has been distinguished from the woman's right to privacy, noting the "[e]xclusion of the unborn from personage under the fourteenth amendment served to advance a woman's constitutional right to privacy, whereas exclusion under a wrongful death statute serves only to

60. Farley v. Sartin, 466 S.E.2d 522 (W. Va. 1995).

61. Id. at 523 .

62. Id. at 534 .

63. In 2003 , the Nebraska Legislature (which is unicameral) passed legislation allowing for a wrongful death cause of action of a fetus regardless of gestational age. NEB. REV. STAT. $\$ 30-809(1)(2003)$. However, the statute excludes a physician from being held liable under this act if the death occurred as the result of a medical procedure in which "the requisite consent was given.” NEB. REV. STAT. § 30-809(2)(b) (2003).

64. On March 25, 2004, the United States Senate passed H.R. 1997, The Unborn Victims of Violence Act, which would permit a separate cause of action for fetuses in federal offenses. Although similar versions of this bill were passed by the House in 1999 and 2001 and failed to receive a Senate hearing, the new designation of the legislation as "Laci's Law," in response to the 2002 death of Laci Peterson and her unborn child in California, which brought increased attention to the bill. It has been noted the legislation further weakens the Roe v. Wade doctrine. However, the key provision in this legislation as it pertains to this issue is medical professionals are specifically excluded from liability under this law. H.R. 1997, 108th Cong. (2004). Carl Hulse, Vote in House Says It's Crime to Harm a Fetus, N.Y. TimEs, Feb. 27, 2004, at A15; Carl Hulse, Senate Outlaws Injury to Fetus During a Crime, N.Y. TiMES, Mar. 25, 2004, at A1.

65. Wiersma v. Maple Leaf Farms, 543 N.W.2d 787, 791 (S.D. 1996). 
immunize a wrongdoer from liability. ${ }^{966}$ In essence, denying any civil liability to the tortfeasor for injuring a fetus is raising protection of the tortfeasor above the woman's fourteenth amendment right to privacy.

The Farley court also observed the social justice and policy benefits in recognizing there is no difference between a quick and a viable fetus and that parents have suffered a loss regardless of the fetus' age. ${ }^{67}$

[J] ustice is denied when a tortfeasor is permitted to walk away with impunity because of the happenstance that the unborn child had not yet reached viability at the time of death. The societal and parental loss is egregious regardless of the state of fetal development. Our concern reflects the fundamental value determination of our society that life - old, young, and prospective-should not be wrongfully taken away. ${ }^{68}$

The Farley court supported this position in stating "the overriding importance of the interest that we have identified merits judicial recognition and protection by imposing the most liberal means of recovery that our law permits." 69

Further, the viability standard, which has kept many states from recognizing fetal wrongful death, is "outmoded in tort law." "Viability as a developmental turning point was embraced in abortion cases to balance the privacy rights of a mother as against her unborn child. For any other purpose, viability is purely an arbitrary milestone from which to reckon a child's legal existence." ${ }^{.11}$ Losing a potential family member due to the tortious conduct of another person causes the woman and family an injury and pain of the same order as when it loses an existing member. ${ }^{72}$

\section{E. The Issue Should Not Die. . Do Not Rely on Medical Malpractice}

Despite the arguments in support of wrongful death, it is not likely to become accepted by a majority of states without an abolition of the viability standard because there is no good standard to determine viability. Further, it is not likely that the more liberal states will entertain the notion of introducing it, especially in states with lenient laws that permit abortions into the second

66. David Kader, The Law of Tortious Prenatal Death Since Roev. Wade, 45 Mo.L. REV. 639,657 (1980).

67. Farley, 466 S.E.2d at 533.

68. Id.

69. Id.

70. Wiersma, 543 N.W.2d at 792.

71. Id.

72. 66 Fed. Credit Union v. Tucker, 853 So.2d 104,107 (Miss. 2003). 
and third trimesters. However, states should be persuaded by West Virginia and South Dakota, which have taken steps to eliminate the barrier of viability in allowing wrongful death claims through case law, and states like Nebraska that have done it statutorily. A woman will not feel the loss of her fetus any less because her fetus is not yet "viable." In states that do not recognize fetal wrongful death and that have undergone medical malpractice reform to limit claims and tighten recovery caps, women in those states who have been harmed in a medical setting will have little potential for successful recovery.

While it is true lawsuits are filed often in this country and many jurisdiction's courts are flooded with cases, such a reason is not a valid excuse to essentially "ignore" a tort because it has been historically too difficult to determine. In actuality, the arena of medical malpractice has become something like a three-ring circus, especially in states that have been labeled "crisis" states. Wrongful death claims are not nearly as time consuming on the courts simply because they do not involve the expansive procedural mandates that accompany medical malpractice claims. Adopting wrongful death is a good choice to make for the states that have been faced with an onslaught of medical malpractice litigation.

However, the problems associated with viability should not prevent a court from recognizing the tort of fetal wrongful death in the case of an unnecessary abortion due to the physician's recommendation. In Rambov. Lawson, the Missouri Court of Appeals noted it understood there is a heightened difficulty in proving that a nonviable fetus was in fact alive at the time of the injury in order to prove causation, but "[d]ifficulty of proof has no bearing on the existence of a cause of action." 73

\section{Medical MaLPRACTICE FOR A Fetal DeATH}

Much of the rise in malpractice insurance premiums in recent years has been attributed to obstetricians. Medical malpractice has become the accepted tort under which to try cases of this nature, although the recent trend toward caps in potential recovery could see a limitation on the situations in which one could recover and the amount that is recoverable. These recent developments could lead to medical malpractice offering even less possibility for recovery by women but, yet it is a more viable option than recovery under wrongful death and the only option in many states with respect to fetal recovery.

73. Rambo v. Lawson, No. WD 41747, 1990 WL 54277, at *5 (Mo. Ct. App. May 1, 1990). The Supreme Court of Missouri affirmed this holding initially, but the court was forced to hold differently in Connor v. Monkem, following the passage of legislation in Missouri stating life begins at conception. Conner v. Monkem Co., Inc., 898 S.W.2d 89, 92 (Mo. 1995). The Connor court said the Rambo holding was not to apply to cases following the effective date of the statute. Conner, 898 S.W.2d at 93 . The court also pointed out that in holding that such a cause of action could exist did not mean that a party would ever be successful in proving a claim. Id. 


\section{A. Standard of Care of an Obstetrician/Gynecologist}

The standard of care for an obstetrician/gynecologist $(\mathrm{OB} / \mathrm{GYN})$ is not necessarily different from any other type of physician. "[A] physician is under a duty to use that degree of care and skill which is expected of a reasonably competent practitioner in the same class to which he belongs, acting in the same or similar circumstances." ${ }^{.74}$ Massachusetts adds the condition that one has to consider the advances in the profession and the resources available to the physician. ${ }^{75}$ Although a court does not have to treat OB/GYNs any differently than other types of physicians, a court is allowed to take their specialized training into account. "Under this standard, advances in the profession, availability of facilities, specialization or general practice, proximity of specialists and special facilities, together with all other relevant considerations, are to be taken into account." 76

\section{B. Burden of Proof: Medical Malpractice Claims}

States tend to differ on the elements that must be met to satisfy the burden of proof for medical malpractice claims. Missouri courts have held three elements must be satisfied to have a prima facie case of medical malpractice: "1) an act or omission of the defendant which failed to meet the requisite medical standard of care; 2) that the act or omission was performed negligently; and 3) a causal connection between the act or omission and the plaintiff's injury." 77 Similarly, Georgia courts also recognize three elements necessary for medical malpractice: 1) the duty that naturally arises from a physician-patient relationship; 2) a breach in that duty by abandoning the requisite standard of care; and 3) that the breach was the proximate cause of the injury. ${ }^{78}$ Georgia's requirements fall neatly within the framework of torts learned in first-year coursework, ${ }^{79}$ yet Missouri introduces the requirement that the act or omission in question be performed negligently, which would be more difficult to prove or attain rather than a mere breach of a duty. Also, in Missouri's first element, "duty" is somewhat veiled under the wording of "requisite medical standard of care." ${ }^{180}$ This suggests Missouri is not looking for a personal duty to a particular patient, but that a medical professional's duty is generally implicit in the medical standard of care.

74. Shilkret v. Annapolis Emergency Hosp. Ass'n., 349 A.2d 245, 253 (Md. 1975).

75. Stepakoff v. Kantar, 473 N.E.2d 1131 (Mass. 1985).

76. Shilkret, 349 A.2d at 253.

77. Baker v. Gordon, 759 S.W.2d 87, 91 (Mo. Ct. App. 1988).

78. Breyne v. Potter, 574 S.E.2d 916, 919-20 (Ga. Ct. App. 2002).

79. Basic tort law involves proving there is a duty between the two parties, a breach of that duty, and the breach was the cause of the injury.

80. Baker, 759 S.W.2d at 91. 
Beyond the elements which appear in case law, states have codified procedural guidelines for filing medical malpractice claims. For many states, especially those which have tried to control the rise in medical malpractice claims; these strict and often lengthy procedural guidelines are likely enacted to curb the filing of frivolous claims. Indiana's procedure is similar to states such as Louisiana and Nebraska. ${ }^{81}$ Under Indiana law, a medical review panel may be convened after the claim has been filed, and the panel consists of one attorney, who acts as the chairman of the panel, and three medical professionals, who must be licensed in their respective fields and may not be a health facility administrator. ${ }^{82}$ The panel receives evidence and information from the respective parties. The panel's report, based on the evidence submitted to them by the parties, is due 180 days after the last person joined the panel. Although the report is admissible as evidence at trial, the panel's report is not controlling or binding upon the court in any way, and it does not even have to be used at trial. ${ }^{83}$

The panelists are to be compensated for their time, which roughly equates to expert testimony fees. ${ }^{84}$ However, the goal of the medical review panel is to provide an objective opinion based on input from both the legal profession and the medical profession. Also, the time consuming nature of this exercise would likely deter some people from wanting to proceed with this route, as it will likely drive up litigation costs.

\section{The Benefits of Medical Malpractice}

Medical malpractice is likely a more successful claim for the woman filing a claim for an abortion based on the incorrect recommendation of the woman's OB/GYN. Medical malpractice usually involves physician error or oversight, which is clearly evident in Breyne v. Potter, where the physician misread the test results twice. ${ }^{85}$ The duty of the physician is easier to determine than the viability of a fetus, as viability is the standard that keeps many states from recognizing wrongful death in fetuses. In the Breyne case, the woman's expert witness testified that the physician "deviated from the standards of care ... by failing to accurately counsel [the woman] concerning the findings," and this deviation deprived her of the chance to make an informed choice and led her to choose an unnecessary abortion. ${ }^{86}$

81. LA. Rev. Stat. ANN. § 40:1299.39.1 (West 2004); NEB. ReV. STAT. $§ 44-2825$ (1993).

82. IND. CODE $\S 34-18-10$ (2003). In Nebraska, the attorney member of the panel is a nonvoting member of the panel. NEB. REV. STAT. $\S 44-2841$ (1) (2003).

83. IND. CODE § 34-18-10 (2003).

84. Id.

85. Breyne v. Potter, 574 S.E.2d 916, 918 (Ga. Ct. App. 2002).

86. Id. at 919. 
Further, many, if not all, states have specific procedures for medical malpractice, and medical malpractice is a widely practiced and utilized area of law. Some mechanism is needed to hold physicians to the standard of duty, and in a situation like the Breyne case, medical malpractice emphasizes the breach of duty of the physician.

\section{Medical Malpractice: Criticized on So Many Fronts}

The prominence of medical malpractice claims in the United States has received a lot of attention from the media and legal scholars alike. Consequently, pressure is rising to cap malpractice suits as one method of cost-containment for health care, and many states have began to limit the amounts of recovery possible from medical malpractice suits. ${ }^{87}$ For example, Louisiana has capped the potential recovery for medical malpractice at $\$ 500,000$, but it allows the court to retain jurisdiction over the matter to make determinations regarding the reimbursement of future medical payments if the court grants permission for that consideration in its initial judgment. ${ }^{88}$ In response to the increase in claims, insurance companies have responded by drastically increasing coverage rates for physicians, and OB/GYNs often top the list of the highest insurance premiums. The increase has made many physicians overly sensitive and anxious about the possibility of being sued. Even before the malpractice insurance rates began to rise, there was a suggestion this type of problem might occur as a consequence of allowing recovery in the first place.

A natural response of $\mathrm{OB} / \mathrm{GYNs}$, in an attempt to avoid any risk of malpractice liability, is to over-utilize prenatal diagnostic testing. ${ }^{89}$ However, ordering excessive tests does nothing but raise the costs of health care even more, which is one of the main driving forces of the states who have taken steps to limit medical malpractice in the first place. Until more states have implemented monetary limits for recovery on medical malpractice to protect the OB/GYNs, the health care system will continue to strain under the weight of OB/GYNs and all physicians being overly cautious.

87. Introduced by the Senate in 2004, the Healthy Mother and Healthy Babies Access to Care Act sought to limit punitive damages "against any person named in a health care lawsuit only if it proven by clear and convincing evidence that such person acted with malicious intent." S. 2061, 108th Cong. $\S 6(a)(1)(2004)$. The bill also sought to cap non-economic damages at $\$ 250,000$. S. 2061, 108th Cong. §3(c) (2004). With respect to state action, over the past eighteen months, Florida, Mississippi, Nevada, Ohio, Oklahoma and Texas have passed tort reform legislation in an attempt to curb malpractice insurance rates. The Americans for Insurance Reform group suggest since these states did not see a drop in insurance rates following the passage of their respective laws, the problem lies more in the insurance industry than in the legal arena or health care arena. Americans for Insurance Reform, Limiting Liability Will Not Fix Insurance Problems, at http://www.insurance-reform.org/pr/AIRCaps\%20then $\% 20$ Rate\% 20Hikes.pdf (updated Apr. 2004) (on file with the Indiana Health Law Review).

88. LA. REV. STAT. ANN. $§ 40: 1299.39$ (F) (West 2004).

89. Alexander Morgan Capron, Tort Liability in Genetic Counseling, 79 CoLUM. L. REV. 618,661 (1979). 
Additionally, there might be a problem with causation, which is one of the requirements in many states for a medical malpractice claim. The physician's negligence is not the proximate cause of the fetus's condition. The fetus's condition is the uncontrollable result of genetics. The physician's alleged negligence in failing to detect the abnormality or genetic defect from the prenatal test is not quite the same scenario as the situation in which a physician has failed to make a timely diagnosis of a curable disease. The affliction the child must live with "is an inexorable result of conception and birth." 90

\section{E. Medical Malpractice: It's Fine for Now}

Nevertheless, the physician's involvement in the Breyne case and other similar situations is one of more direct causation. True, the physician may not have anything to do with the child's genetic make-up, but a woman's obstetrician is the person the woman entrusts to advise her on the best course of treatment or action during her pregnancy. If a woman terminates the pregnancy because her physician informed her she would have a child with severe defects, and the physician turned out to be carelessly wrong, the physician is within the chain of causation. The woman would testify if she had not been told of the abnormality she would not have elected pregnancy termination.

In the push to reform the tort of medical malpractice, it is possible to lose sight of the patients' role in the situation. True, the rise of medical malpractice has led to the rise of insurance premiums, but consider the probable reason for those large increases: hospitals have to raise rates to cover in kind services to people who cannot pay. It would be an injustice for the hospitals and subsequently, society as a whole, to bear the costs of other people's wrongdoing. "To deny recovery, as the courts have, because professional liability would otherwise be greatly increased is merely to pretend that the costs created by professionals' wrongful conduct do not exist . . . they are merely less visible, being borne by the victims or by the state and other groups in society."

The other major factor that is forgotten in medical malpractice is the termination of the pregnancy. Medical malpractice is better suited to cases in which the doctor operates on the wrong extremity, but when the malpractice is a loss of life, there does not seem to be the completeness of recovery or the closure that may come from a wrongful death suit. Wrongful death acknowledges the potential of human life, and medical malpractice merely chastises human error.

90. Grubbs v. Barbourville Family Health Ctr., 120 S.W.3d 682, 689 (Ky. 2003) (quoting Becker v. Schwartz, 386 N.E.2d 807, 816 (N.Y. 1978)).

91. Capron, supra note 89, at 684 . 


\section{Does the Right to Choose PREClude the Right to SuE?}

\section{A. The Effect of the Woman's Voluntary Abortion}

Perhaps the most significant component of the Breyne v. Potter case is the ethical conflict that came into play regarding the woman's choice to abort the fetus. ${ }^{92}$. There is an ethical dilemma with regard to what extent the woman's choice to terminate the pregnancy affects the wrongful death claim or the medical malpractice claim in states that do not recognize wrongful death. The conflict centers largely around the designation of the fetus. States that recognize fetal wrongful death, like Georgia, do so on the premise that the fetus is a person or at the very least, an independent being from its woman. However, this philosophy contradicts the reasoning of the Supreme Court's interpretation of an unborn child's status in Roe v. Wade. ${ }^{93}$ The Roe Court held an unborn child is not a person to the specific terms of the Fourteenth Amendment, yet it seemed to acknowledge the difference between the designations of a person necessary to support both wrongful death and abortion. ${ }^{94}$ Author Sheryl A. Symonds explains the Roe Court's reasoning behind distinguishing the policy motives behind wrongful death and abortion:

[T] he decision to allow abortion does not depend on the same policies and justifications as does the decision to allow a cause of action for the wrongful death of a fetus. While the fetus may not be a "person" for the purposes of the fourteenth amendment, it may be a "person" for the purposes of a states' wrongful death statute. Furthermore, while a woman's right to privacy is the policy involved in the abortion decision, the policy that a tortfeasor should not escape liability is involved in the wrongful death decision. One decision does not solve the controversy of the other. ${ }^{95}$

\section{B. Another Conflict over Viability}

Although it appears the Roe Court tried to preserve the possibility of a world in which wrongful death suits and the choice to have an abortion can coexist, there is one common theme running through both wrongful death and abortion-viability. With the exception of South Dakota and West Virginia,

92. Breyne v. Potter, 574 S.E.2d 916 (Ga. Ct. App. 2002). Abortions for some clinical reason, like a health problem or an identified genetic disease, account for approximately two percent of all abortions performed in the United States annually. Klasing, supra note 49, at 973.

93. Roe v. Wade, 410 U.S. 113 (1973).

94. Id. at 158 .

95. Farley v. Sartin,466 S.E.2d 522, 534-5 (quoting Sheryl A. Symonds, Wrongful Death of the Fetus: Viability is not a Viable Distinction, 8 U. PUGET SOUND L. REV. 103, 113 (1984)). 
viability is a requisite for most states' wrongful death claims. " "“[V]iability' as a developmental turning point, was embraced in abortion cases to balance the privacy rights of a woman as against her unborn child. For any other purpose, viability is purely an arbitrary milestone from which to reckon a child's legal existence.",97

Further, the Supreme Court revisited the idea of viability and the trimester framework in Planned Parenthood v. Casey in $1992 .{ }^{98}$ Viability was recognized as a crucial element of the Roe holding, which was affirmed by the Casey Court: "subsequent to viability, the State in promoting its interest in the potentiality of human life may, if it chooses, regulate, and even proscribe, abortion except where it is necessary, in appropriate medical judgment, for the preservation of the life or health of the mother." 99 However, the Casey Court rejected the "rigid trimester framework" of Roe and held the "undue burden" standard is more appropriate. ${ }^{100}$ According to the Court, an undue burden exists if something becomes a substantial obstacle or interference to the mother being able to obtain an abortion before the viability of the fetus, unless the life of the mother is in jeopardy. ${ }^{101}$

The Casey Court acknowledged the importance of stare decisis with respect to the Roe decision since it has become the foundation of much of the abortion law in this country, but it could be argued that in doing so, it did nothing but confuse the matter even further. The viability standard, which is the lucid element on which many prenatal torts lie, was not eliminated but rather nearly exalted in Casey. Stare decisis does little for a jurisprudence if that law is of little help to legislatures and lower courts in applying the rule. At least the trimester framework provided concrete dates on which a court could rely. Instead, the abolition of the trimester framework in Casey did nothing but frustrate the purpose, as now, more than ever, the issue of viability is left to the speculation of individual states and courts, which may ruin the effect of Roe more than overruling it.

\section{Is the Woman Contributorily Negligent?}

Irrespective of the viability issue, the woman's decision to have an abortion can potentially affect the alleged negligence of the physician. The Georgia Court of Appeals held in Roseberry v. Brooks that the physician's negligence is superseded by a woman's choice to have an abortion. ${ }^{102}$ In

96. See Part II.C, supra.

97. 66 Fed. Credit Union v. Tucker, 853 So.2d 104,114 (Miss. 2003) (quoting Wiersma v. Maple Leaf Farms, 543 N.W.2d 787, 792 (S.D. 1996)).

98. Planned Parenthood v. Casey, 505 U.S. 833 (1992).

99. Id. at 838 (quoting Roe v. Wade, 410 U.S. 113, 164-65 (1973)).

100. Id.

101. Id.

102. Roseberry v. Brooks, 461 S.E.2d 262, 267 (Ga. Ct. App. 1995). 
Roseberry, the woman's primary care physician recommended that she have an abortion based on his belief that the fetus would likely die due to the woman's liver disease. ${ }^{103}$ The physician did not consult with an obstetrician prior to giving the woman this advice, and she had an abortion based on his recommendation. ${ }^{104}$ Later, it was determined her treatment for the liver disease probably would not have damaged the baby, but the court held that "any medical negligence attributable to [the physician] is superseded by the mother's volitional act as the proximate cause of the death of the fetus."105

The court reasoned the woman's act created a problem with causation, stating "[t]he lawful abortion performed for that purpose [for the woman to undergo cancer treatment] is an intervening act which effectively caused the entire injury (death) to the unborn [fetus]."106 The physician was not the proximate cause of the fetus' end of potential life. ${ }^{107}$

Conversely, a Michigan physician did not escape liability in Barnes $v$. Vettraino. ${ }^{108}$ In Barnes, the woman had an amniocentesis due to her age, which was thirty-six. There was a delay in the results being relayed to her, and when she finally received the results, she learned the baby had various birth defects. Michigan law prevented her from having an abortion because of the fetus's gestational age, so the woman traveled to a different state for the abortion, and she suffered complications from the procedure. She filed a claim based on the costs associated with the abortion and did not file an express claim of wrongful death. ${ }^{109}$ The Barnes court noted the parents were seeking medical malpractice damages "for economic and non-economic losses attributable to a medical provider's purported negligent diagnosis and treatment," and held that just because "these losses arose in the context of an abortion does not prevent the plaintiffs from pursuing compensation." was very deliberate to clarify the damages granted to the parents did not establish a "wrongful infliction of abortion" cause of action. ${ }^{111}$

The Barnes court limited the holding of its previous decision in Taylor v. Kurapati. ${ }^{112}$ Taylor held the state "has no obligation to take the affirmative

103. Id. at 267.

104. Id.

105. $I d$.

106. Id.

107. Roseberry v. Brooks, 461 S.E.2d 262, 267 (Ga. Ct. App. 1995).

108. Barnes v. Vettraino, No. 235357, 2003 Mich. App. LEXIS 801 (Mich. Ct. App. Mar. $25,2003)$.

109. Id. at *1-2.

110. Id. at *7.

111. Id.

112. Taylor v. Kurapati, 600 N.W.2d 670 (Mich. Ct. App. 1999). In Taylor, the woman's initial ultrasound was interpreted by her $\mathrm{OB} / \mathrm{GYN}$, who indicated that there were no problems. The second ultrasound was performed and interpreted by another physician, who indicated to the mother that she might want to have a high-resolution ultrasound because she could not identify the fetus's femurs. The mother refused, since her OB/GYN previously told her the baby merely had short femurs. The baby was born missing a femur, shoulder, fingers and with several fused joints. Id. at 673-74. 
step of imposing civil liability on a party for failing to provide a pregnant woman with information that would make her more likely to have an elective, and eugenic, abortion," because the state does not have to assist a woman who wants an abortion by paying for it. ${ }^{113}$

The Taylor court recognized the ethical conflict between abortion and wrongful death, stating that " $[t]$ here would be an inherent conflict in giving the woman the right to terminate the pregnancy yet holding that an action may be brought on behalf of the same fetus under the wrongful death act" for the negligent act of the third party. ${ }^{114}$

However, it is possible that the "conflict," to which the Taylor court refers and the reason for the Barnes court's careful limitation of its decision to medical malpractice (rather than wrongful death), is non-existent in modern jurisprudence. Wrongful death actions for a fetus and an abortion might be able to coexist, especially because "[t] he irrelevance of Roe v. Wade to the question of recovery for the wrongful death of a stillborn fetus may be inferred from the numerous post-Roe decisions which do not rely on it in any respect ...."115 Further, Roe bases its interpretation of person on the Fourteenth Amendment, which is nineteenth century law. The Framers of the Constitution and those who have since amended it have all intended for the interpretation of the document to be flexible and capable of withstanding changes in society, including changes in the medical landscape that might allow for a broader definition of person.

Finally, as aforementioned in this Part, Roe itself notes there is a difference in the definition of person for the purposes of wrongful death and for abortion. ${ }^{116}$ Society may be better off if all aspects of the law (case law,

113. Id. at 687. This view of the Taylor court seems to ignore the whole idea of informed consent, which was in existence in the context of abortion at the time of this decision. At the time of the Taylor decision, Michigan had an informed consent law concerning abortion procedure, which would essentially prevent any patient from having an "elective" abortion, as it requires the mother to undergo certain steps and sign various release forms before she has an abortion. MiCH. COMP. LAWS ANN. §333.17015 (West 2003). Similar informed consent was missing in the Taylor case, which failed to recognize the failure of the physician in this case. Case law in Michigan suggests that the question whether an abortion should be performed in the first trimester is left to the discretion of the physician. See, People v. Nixon, 201 N.W.2d 635 (Mich. Ct. App. 1972). However, following the passage of the informed consent statute specifically concerning abortion, it would seem the physician should have a duty to inform the woman of the option to terminate the pregnancy in a non-coercive manner and let her have the benefit of making the decision herself, rather than essentially having the physician do it for her. This lack of correct information led the woman in the Taylor case to deliver a child she would have terminated and the woman in the Breyne case to terminate a pregnancy of a normal fetus.

114. Kader, supra note 66, at 657 (quoting Toth v. Goree, 237 N.W.2d 297, 301 (Mich. Ct. App. 1975)). "[A]bortion involves the 'intentional, consensual act by a woman and her physician, which the law specifically allows,' and since the law allows it, the law should protect the woman whose consent was given based on misinformation. Klasing, supra note 44, at 971.

115. Kader, supra note 66, at 651 .

116. Roe v. Wade, 410 U.S. 113, 162 (1973); see also, Sheryl A. Symonds, Wrongful Death of the Fetus: Viability is not a Viable Distinction, 8 U. PUGET SOUND L. REV. 103, 113 (1984). 
statutes and policy) recognize "it may be necessary to accept some inconsistency and conclude that prenatal life will be protected against intentional or negligent interference, absent some compelling countervailing interest on the part of another." 117 The physician would have to prove that there was some "compelling countervailing interest" that prevented him or her from acting accordingly. Applying this standard to the Breyne case might lead to the conclusion the physician's mistake in reading the laboratory report was not a compelling interest to protect the life or interest of the fetus.

\section{Prenatal Genetic Testing and Abortion}

This "compelling countervailing interest" standard might lead physicians to adopt a new standard in which they do not order any prenatal testing, reasoning that as physicians, their only compelling interest is to protect the life of its patient (here, the fetus). It could be argued that standards of care are constantly evolving which would permit a rapid change in the standard of prenatal care. Also, advances in genetic mapping have put strains on prenatal testing from the standpoint that it gives women too much information that may not be completely accurate.

A better solution to this problem, rather than wasting judicial time with a whole new set of claims of women's privacy violations, is to preclude any physician liability based on anything related to a prenatal test or eliminate the standardized practice of recommending abortions based on prenatal tests. In Simmons v. W. Covina Med. Clinic, ${ }^{118}$ a California Appellate Court realized the genetic test is not foolproof. In Simmons, a woman's physician failed to administer an AFP test, and her son was born with Down's Syndrome. ${ }^{119}$ The woman said if she had known her child would have been born with Down's Syndrome, she would have terminated the pregnancy. Nonetheless, the court noted the AFP test was initially administered to detect neural tube defects like spina bifida and only recently was it discovered that in twenty percent of cases involving women under thirty five years of age, ${ }^{120}$ the test could identify factors indicative of the possibility of having children with Down's Syndrome. The court held these percentages were not strong enough to attach liability to the physician. ${ }^{121}$

It is unlikely the practice of aborting a fetus based on the result of a prenatal test will be eliminated. However, if the choice is made to terminate

117. Kader, supra note 66 , at 660 .

118. Simmons v. W. Covina Med. Clinic, 212 Cal. App. 3d 696 (Cal. Ct. App. 1989).

119. Id. at 699 .

120. The age is significant in this case because at the time of this decision, amniocentesis was typically only performed on women over the age of thirty-five. AFP testing, which is performed on all pregnant women, was a younger woman's only possibility for detection of the risk for Down's Syndrome, and even then the AFP test did not detect the presence of Down's Syndrome in all cases. Id. at 700 .

121. Id. at 696 . 
the pregnancy based on the result of a prenatal test, "[e]very effort should be made to confirm the chromosome abnormality in the abortus itself." 122 Confirming the abnormality is important to the extent that further tests can be conducted to determine whether the parents are carriers of a gene. The medical analysis is important research into the genetic make-up, which could further the advances of the Human Genome Project. Further, pathological analyses are routine in this country to confirm a diagnosis or to learn more about an affliction. Even though parents can have a difficult time understanding the purpose of the pathological testing and it can potentially create problems for physician liability, it is unlikely the practice will end due to its research benefits.

\section{E. The Doctor's Only Choice is to be More Careful}

Abortion is a difficult decision under any circumstance, and for women and families faced with the uncertainty of having a severely deformed child, it appears like the best option to some women. To have that mindset confirmed by the woman's physician (that the pregnancy should be terminated) would be the only words some women would need to hear if they were unsure about their feelings.

Society tends to usually place a high level of confidence in their physician's opinion, especially when faced with such a decision of grave consequences. The physician's recommendation to terminate the pregnancy will help give some form of closure to a woman and validation for her decision. If this recommendation turns out to be faulty and the baby was in fact healthy at the time of termination, similar to the situation in the Breyne case, a woman should be allowed to recover from the termination that would not have happened but for the physician's recommendation. "[T]he fact that the [death] in question occurred at the time of the therapeutic abortion does not preclude [a woman] from maintaining this action if the trier of fact concludes that said abortion was necessitated because of injuries sustained as a result of the negligence of appellees." 123 Here, the injury is not a physical, battery-like injury, but the injury is a recommendation by a trusted physician to terminate the pregnancy.

If physician's negligence is truly the major motivating factor in a decision to terminate the pregnancy; that is, the parents did not reach the decision by themselves, then the physician's negligence should not be superseded by the woman's choice of termination. The physician should be held not only to a duty to give information about all options but to ensure the information is correct, or otherwise there is a lack of "informed consent." As long as women have the right to choose to have an abortion, which stems from a fundamental

122. Priest \& Rao, supra note 15 , at 211 .

123. Shirley v. Bacon, 267 S.E.2d 809, 811 (Ga. Ct. App. 1980). 
right to privacy, that right should be protected up until viability, and the severity of its consequences should be considered and respected by obstetricians who must tread in its murky waters.

\section{CAN THE LAB OR GENETIC COUNSELOR DOING ANALySis BE HELD JOINTLY/SEVERALLY LIABLE?}

Although it appears steps are being taken towards allowing a separate cause of action for a fetus, pending medical malpractice legislation could result in a cap being placed on the maximum potential recovery for an OB/GYN. This would greatly limit the possibility for recovery from OB/GYNs for a fetus with newly gained legal recognition, at least for federal crimes. ${ }^{124}$ The result of this event could make the lab conducting the genetic testing or the genetic counselor who meets with the parents more vulnerable to lawsuits. Even when the genetic counseling was in its formative stages, there was a movement to hold genetic counselors to a similar duty as other medical professionals, although noting that some exceptions might have to be made since they can possess a different education background than physicians. ${ }^{125}$

Further, if the problem with the prenatal test is traced not to the physician's oversight but rather to faulty equipment used to obtain the sample or analyze the sample, this would not be a claim under medical malpractice but would fall under general negligence or product liability. For example, Indiana's Medical Malpractice statutes only apply to medical judgments by professionals. ${ }^{126}$ This is beneficial to the women because it could allow them to escape the caps that some states have imposed on recovery for medical malpractice claims.

In Indiana, it appears there would be a cause of action against the genetic counselor and his/her employer under traditional medical negligence. In Bader v. Johnson, a woman who had previously given birth to a child with hydrocephalus consulted a genetic counselor for an amniocentesis and an ultrasound, based on the fact that if she was carrying a similarly afflicted child in this pregnancy, she would terminate the pregnancy. While the amniocentesis revealed no abnormalities, the ultrasound indicated a possibility of hydrocephalus because the fetus had a large head. The woman was supposed to return to talk to the counselor, but an office error caused her to not be scheduled for a follow-up appointment. Her "treating physician" performed another ultrasound at thirty-three weeks, which confirmed the fetus had hydrocephaly, but it was too late for an abortion. The child died at the age of four months, and the parents sued the genetic counselor and the laboratory/practice

124. See Part II.D, supra.

125. Genetic counselors typically have a master's degree in genetic counseling and their bachelor's degrees typically are in either the sciences or psychology. They must also be board certified by the American Board of Genetic Counselors. Malinowski, supra note 12, at 1459.

126. IND. CODE § 34-18-12-18 (2003). 
as a whole. ${ }^{127}$ In their complaint, the couple alleged "they consulted Healthcare Providers to obtain information having a direct bearing on [the woman's] health, namely: a decision to terminate the pregnancy." 128 The ultrasound was conducted by Healthcare Providers revealing pre-natal abnormalities. The couple relied on the results of the ultrasound to make their informed decision. The Indiana Supreme Court stated "[a]s a matter of law Healthcare Providers owed a duty to the [couple] to disclose the result of the test" ${ }^{129}$ and failing "to allow the [couple] to proceed with their claim would 'immunize those in the medical field from liability for their performance in one particular area of medical practice." "'130

The Delaware Supreme Court concurs with Indiana's result, "recognizing a cause of action for negligent performance or delay in diagnostic testing for birth defects, either under the guise of traditional tort analysis or 'wrongful birth."'131 Louisiana's Malpractice Liability for State Services Act would provide that laboratories in state-operated medical facilities could be held vicariously liable, but the $\$ 500,000$ cap on awards for damages would apply comprehensively to all involved parties in the action. ${ }^{132}$

Conversely, there are strong policy arguments to support that prenatal diagnostic laboratories and their genetic counselors should not be held liable for faulty test results. The lab employees do not have the same skill and education as the physicians do. Genetic counselors, who are usually employed by the labs analyzing the tests, typically have undergraduate degrees in some discipline of science, they have a master's degree in genetic counseling, and they have to be board-certified by the American Board of Genetic Counselors. ${ }^{133}$ Also, the diagnostic labs themselves are highly sensitive to the legal and medical liability associated with genetic testing. If there is any question about the quality of the specimen that has been obtained or a question about the process of the analysis, the lab will usually recommend a follow-up or repeat test just to be safe. ${ }^{134}$

It appears while the prenatal diagnostic laboratories can be held jointly liable, with some states like Louisiana mandating that the medical malpractice

127. Bader v. Johnson, 732 N.E.2d 1212, 1215-16 (Ind. 2000).

128. Id.at 1217.

129. Id.

130. Id. at 1219 (quoting Garrison v. Foy, 486 N.E.2d 5, 8 (Ind. Ct. App. 1985)).

131. Garrison v. Med. Ctr. of Delaware, Inc., 581 A.2d 288, 292 (Del. 1989).

132. LA. REV. STAT. ANN. § 40:1299.39(A), (F) (West 2004). Based upon Louisiana courts' applications of the statute, the cap would apply both to staff employees of the hospital or contracted staff of the hospital. Therefore, if the OB/GYN was on the hospital staff or on contract with the hospital, then the maximum allowed for recovery would be $\$ 500,000$. However, if the state-funded laboratory is merely the only testing facility in the area to which all tests are sent and the physician has no connection with the facility, it is unclear whether a separate cap would be possible for the laboratory and the OB/GYN.

133. Malinowski, supra note 12, at 1459.

134. Id. at 1465 . 
damage cap apply to all liable parties, ${ }^{135}$ public policy would discourage the possibility of holding the labs severally liable unless a strong showing could be made of intentional negligence on the part of the laboratory. This position insulates the laboratory and its employees to a certain extent by recognizing their level of education is usually less than that of a physician. This position would greatly help in situations like the Breyne case. The diagnostic laboratory had properly performed the genetic test; it was the physician that misread the results.

It is not likely there would be a completely separate cause of liability because, typically, as in the Breyne case, the woman's OB/GYN is involved in the process, either in administering the prenatal test or discussing the results with the woman. As genetic counselors become more prominent in the field of genetic testing and as prenatal genetic testing stands to greatly expand its potential due to the Human Genome Project, there will be more pressure on the genetic counselors and prenatal diagnostic laboratories. The result is their roles in the process could become more prominent and certainly expanded. The scope of their duty and the level of their education should be addressed, including the possibility of mandating a medical degree or at least specialized medical training.

\section{CONCLUSION}

Breyne v. Potter is only the beginning of this issue. As the Human Genome Project draws to a close, that information is going to begin to appear within the context of prenatal genetic testing. Scientists are undoubtedly going to identify more chromosomal abnormalities that can be detected through already-utilized prenatal testing methods. This will naturally lead to more instances for misdiagnosis or misinterpretation, either by the physician or the prenatal diagnostic laboratory and could open the door for more healthy fetuses aborted based on the belief they had a gross genetic abnormality.

As technology develops, the law has to be able to appropriately respond to situations in which technology leads to unfortunate results. The opportunity for abortion exists in our society, and a woman's right to choose to have an abortion has been recognized as a fundamental right stemming from her right to privacy. Supreme Court cases in the years following Roe v. Wade have sought to refine that right, and the right now hinges on a determination of viability, rather than a trimester framework. This is where the issue becomes problematic: viability is often the benchmark by which states determine whether there is a possibility for recovery under the tort of wrongful death for a fetus. Depending on what state a woman lives in, her right to choose to terminate her pregnancy occurs sooner than women in other states, depending on when the state says that a fetus is viable. This discrepancy in states' 
handling of viability could arguably be close to a denial of equal protection because the uniform trimester approach proposed in Roe v. Wade was overruled by the Supreme Court in Planned Parenthood v. Casey in favor of adhering to the viability issue to determine whether abortion is permitted.

More states should be persuaded by those like West Virginia, Georgia, and South Dakota who have abolished the viability standard as the main element in their wrongful death jurisprudence. In cases where the decision to terminate the pregnancy was made at the hands of a physician who negligently read test results, that termination is nothing more than what the tort implies: a wrongful death of an otherwise healthy fetus that came at the hands of the physician.

Medical malpractice is an acceptable means under which to bring this type of claim and is the only method to bring a claim of this type in states that do not recognize a wrongful death cause of action for a fetus. However, as tort reform continues to be a concern and on the agendas of many legislators, limits on potential recovery may not adequately compensate the victim. Essentially, this allows the physician-tortfeasor to escape some of the liability for his/her actions.

The mother's choice to terminate the pregnancy does not mitigate her harm in any way. Her right to choose to terminate her pregnancy is not superseded by her physician's duty to her and her fetus. It is up to OB/GYNs who are going to recommend an abortion to a woman carrying a fetus with gross genetic abnormalities to double check the results, either by having another physician or nurse look at the laboratory results or by verifying the information with the actual laboratory. These measures only take a moment and can be the difference in a situation like the Breyne case. As long as the woman has the right to choose to have an abortion, that right and its consequences must be respected by her physician through a dissemination of correct information regarding her prenatal test results. Although the laboratory who analyzes the test or the genetic counselor involved in the matter may be held vicariously liable, it is unlikely that a separate cause of action will be successful against them due to their inferior education and lack of patient duty.

However, all of this could change as society knows more about genetics than ever before, and it is going to affect prenatal testing. As Roe and the tort of medical malpractice face uncertain futures, a woman with a similar claim to the one in the Breyne case could have no judicial or statutory remedy on which to rely, which would be a great injustice. States should be prepared to reexamine fetal wrongful death with the reminder that just as the law can change, medicine will also change, and our society must look to a way in which the two can exist, respectful of each field's benefits and dangers to society. 